\title{
Not Known if NF1 Mutation Analysis Was Performed
}

National Cancer Institute

\section{Source}

National Cancer Institute. Not Known if NF1 Mutation Analysis Was Performed. NCI

Thesaurus. Code C160461.

An indication that it is not known whether NF1 mutation analysis was performed during the study. 